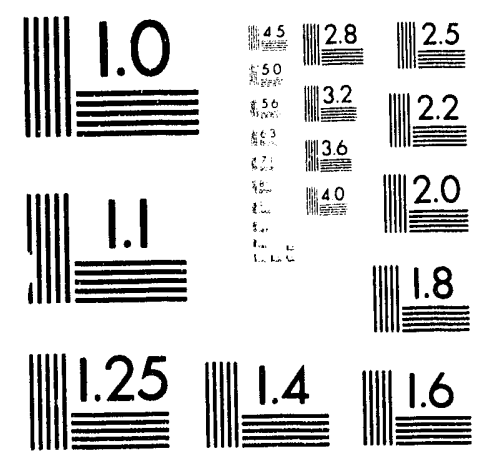



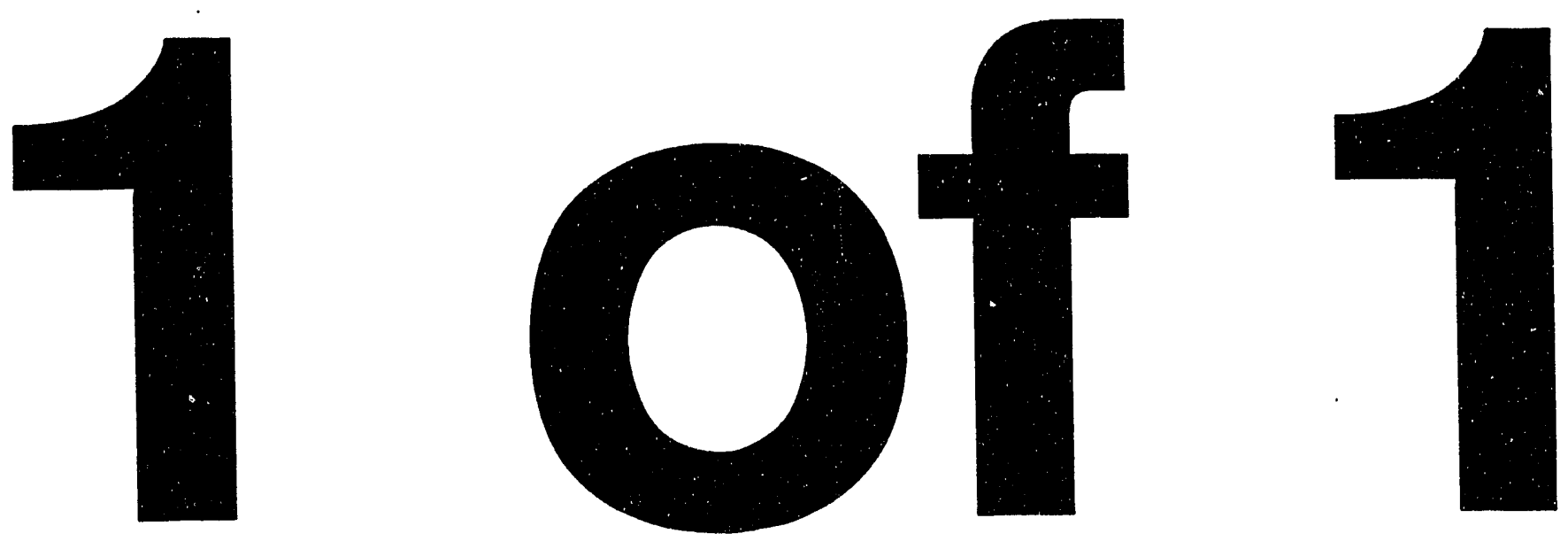


\title{
Neptunium Storage at Hanford
}

\author{
C. J. Alderman \\ S. S. Shiraga \\ R. A. Schwartz \\ R. J. Smith \\ D. W. Wootan
}

Date Published

June 1993

To Be Presented at

11 th Symposium on Space

Nuclear Power and Propulsion

Albuquerque, New Mexico

January $9-13,1994$

Prepared for the U.S. Department of Energy

Assistant Secretary for Nuclear Energy

\section{(2) Westinghouse \\ P.O. Box 1970 \\ Hanford Company Richland, Washington 99352}

Hanford Operations and Enginecring Contractor for the

U.S. Department of Energy under Contract DE-AC06-87RL10930

Copyright License By acceptance of this article, the publisher and/or recipient acknowledges the U.S. Government's right to relain a rioriexclusive, royilly.liou license in and to iny copyriglt oovering thr. paper.

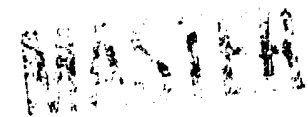

Approved for Public Release 


\title{
NEPTUNIUM STORAGE AT HANFORD
}

\author{
C. J. Alderman \\ S. S. Shiraga \\ R. A. Schwartz \\ R. J. Smith \\ D. W. Wootan \\ Westinghouse Hanford Company \\ P.O. Box 1970, MSIN H0-37 \\ Richland, WA 99352 \\ (509) 376-1796
}

\begin{abstract}
A decision must be made regarding whether the United States' stockpile of neptunium should be discarded into the waste stream or kept for the production of Pu-238. Although the cost of long term storage is not inconsequential, to dispose of the material means the closing of our option to maintain control over our Pu-238 stockpile. Within the Fucls and Materials Examination Facility at Hanford there exists a remotely operated facility that can be converted for neptunium storage. This paper describes the facility and the anticipated handling requirements.
\end{abstract}

\section{Introduction}

The United States has produced and accumulated neptunium (Np) over the last 30 ycars as a byproduct of weapons production. Most of it has been separated from the targets and was being stored for use in creating Pu-238 prior to the conclusion of the cold war. With the change in the political arena and the resultant shutdown of weapons material production, a determination must be made on whether to retain the neptunium, or dispose of it in the high level waste stream. No matter which choice we make, there will be costs involved in processing and storage. The question is whether to pay those costs now and retain the ability for domestic production of $\mathrm{Pu}-238$, or whether to pay the costs of processing it for disposal at a later date. Although the material's high radiation makes it difficult to handle, if processed in a timely manner, the United States has the capability to store it for future use.

A nuclear material storage area was constructed in the Fucls and Materials Examination Facility (FMEF). However, this effort was ended in 1988. The storage area was completed and the resulting vault-type room has the capability of storing the existing neptunium supply. An adjacent room to the storage area was construcied to support receiving and nondestructive assay of the material and appropriate services are in place to accommodate these processes.

Shipping requirements, shipping packages, receipt inspection, and projected dose rates for the shipping of neptunium are considered in following sections. At least three shipping casks are capable of transporting the material and triple pack food cans should prove acceptable for the actual storage container. With some development, nondestructive receipt inspections can be performed on these shipments, and by carefully controlling material impurities and isotopic content, dose rates can be achieved that will meet the U.S. Department of Transportation limits.

\section{STORAGE AREA DESCRIPTION AND STATUS}

The existing storage area is located on the 21-foot level of the FMEF. It is a heavily shielded area designed to automatically store materials. The storage hardware consists of the following: a storage/retrieval machine, an industrial robot, a vertical conveyor system, a bar code reader, and a metric balance. All equipment is computer controlled with an accountability computer in supcrvisory 
control. The area was designed to be operated as a clean vault with fresh air atmosphere. Personnel access to the room is through a vault door. Material access into the room is made via the vertical conveyor system.

The concrete used for the walls, ceiling, and floor surrounding the storage room is normal density concrete, primarily for neutron shielding. All hardware listed above has been installed and preoperationally demonstrated. Actual storage locations consist of two 10 by 13 foot storage rack arrays with 130 storage locations that each hold one storage pallet. Pallets are made of concrete (for neutron shielding) and are designed in two configurations. There are currently 120) six-hole pallets and 138 twohole pallets. New pallets, using the six-hole configuration, will probably need to be fabricated with appropriate gamma shielding for Neptunium storage.

\section{RECEIPT AND VERIFICATION}

All shipping and receiving arrangements must be agreed upon by the supplier, receiver, and the U.S. Department of Energy and are governed by DOE Order 5633.3A. The receiving contractor must be capable of making measurements for receipt verification. Verification, which must provide an accurate account of the shipment's isotopic content, does not necessarily imply chemical assay. In fact, nondestructive assay is not only acceptable, it is preferable to reduce the risk of contamination to the receiving facility.

Arother option is to have the receiver verify the shipment at the supplier's site, then verify the received containers and seals. This has been successfully used in the past and may be the most appropriate method for neptunium shipments. This minimizes the shipping/receiving costs and equipment investment. Once in storage, material survcillance techniques compatible with the DOE philosophy are required on the accountable nuclear material.

\section{FEASIBILITY OF NONDESTRUCTIVE ASSAY}

Although requiring some development, nondestructive assay (NDA) appears to be a feasible method for receipt verification of neptunium shipments. As pressure has increased relative to waste shipment and storage criteria, NDA improvements are being sought (Nicholas, Coop, and Estep 1992). NDA inspection systems are dependent upon the isotopic content of the shipment and the level to which accuracy is required. Potential techniques include any one or a combination of passive and active gamma scanning, and passive and active neutron scanning (Kecpin 1968). In passive gamma scanning, the sample is rotated in front of a collimated detector at several axial increments while gamma spectra are collected. A more complex variation includes a pin-hole gamma camera and a charged coupled detector device to generate real-time images of the entire sample. Image processing can provide quantitative evaluations. Passive gamma scanning is non-invasive and can be done remotely with the sample and positioning mechanism inside a hot cell and the detector and electronics outside. However, isotopic impurities such as U-235 and Pu-239 cannot be readily detected by this method.

Active gamma interrogation involves brief exposure of the material to an intense gamma ray field and analyzing for prompt photofission neutrons. The gamma rays are produced by an electron linac where the bremsstrahlung radiation from the tungsten or tantalum converter is directed to the sample. The gamma rays induce fission in the target material and the resulting fast neutrons are detected. Gross evaluation of total isotopic content susceptible to photofission is obtained.

To quantitatively detect fissile impurities, neutron scanning is required. Passive neutron scanning generally involves $\mathrm{He}-3$ gas proportional counters embedded in a polycthylene moderator surrounding a well containing the sample. Neutrons originating in the sample from alpha, n reactions or spontancous fissions can be detected and analyzed. For $\mathrm{Np}-237$, this type of system might be used to determine the approximate Pu-238 content if the Pu-238 were the dominant alpha producer. 
Active neutron interrogation, exposing the material to a neutron source and analyzing for prompt and delayed neutrons and gammas, can provide a quantitative measurement of all isotopes in the material. A californium shuffler briefly exposes a moderated $\mathrm{Cf}-252$ neutron source to the material and neutron detectors are used to analyze the delayed neutrons. A pulsed neutron differential dieaway system bombards the material with a bricf pulse of neutrons from a neutron generator and neutron detectors are used to analyze the prompt fission neutrons between pulses. The differential dicaway system is more sensitive than the californium shuffler in detecting small fissile quantities (c.g., mg U-235).

Passive and active neutron measurement systems can be combined to increase efficiency. Passive measurement produces a more accurate result for plutonium (Menlove and Eccleston, 1992), but is affected by the packaging matrix. Matrix errors can then be corrected when the data are compared to that gathered from an active measurement. The same type of error correction can be made with a combination passive and active gamma scanning (Martz et. al. 1992). Neutron and gamma ray measurements can also be combined to improve accuracy (Brodzinski and Turner 1990)).

While all of these methods have been used in various applications, a system specifically designed to nondestructively assay neptunium requires development, fabrication, testing, and calibration before it can be used for receipt inspections. The cost and schedule would depend upon the method chosen.

\section{REVIEW OF APPROPRIATE SHIPPING PACKAGES}

Offsite shipping packages must conform to the Department of Transportation (DOT) and U.S. Nuclear Regulatory Commission (NRC) regulations per U.S. DOE-Richland Operations Office (RL) Order 5480.1, Chapter 3, p. iii. A search of the Radioactive Materials Packages (RAMPAC) Database system in Oakridge revealed 10 packages for evaluation. Of those 10, the following 4 packages show potential for use in the neptunium shipments:

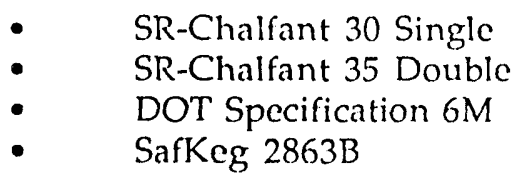

\author{
DOE COC USA $/ 9965 / B(U) F$ \\ DOE COC USA/9968/B()F \\ DOT 49 CFR 173.416 \\ Not Yet Certified.
}

Three commercial packagings are available, however they are heavy and their availability is unknown. If the neptunium shipments contain U-232 and Th-228 impurities of any significant level, these packagings may require further cvaluation because of their shiclding capacity.

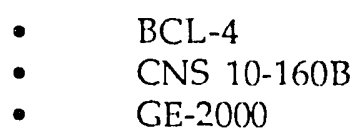

- BCL-4

- $\quad$ GE-2000

\author{
NRC COC USA /5950/B()F \\ NRC COC USA $/ 9204 / B(U)$ \\ NRC COC USA $/ 9228 / B(U) F$.
}

The two Chalfant, the DOT 6M, and the SafKeg packages are of similar design. Both the Chalfant and SafeKeg packages provide leak testable inner containment vessels while the DOT package is not testable. The DOT 6M is neither a NRC nor DOE licensed package and is expected to be eliminated within the next 5 to 10 years. The Chalfant package is expected to be licensable for the next 10 years and the SafKeg package should be certified within the next 2 years. The choice of shipping package should include the package availability and licensability.

\section{Internal Packing}

The available combinations of internal packing number in the hundreds. For the purposes of this study, we assumed the following configuration:

- Innermost can: 3.5-inch-diameter x 3.5-inch tall by 0.010-inch-thick, stecl, "One-Pound Slip Lid Can" 
- Secondary can: 4.063-inch-diameter by 4.625-inch-tall x 0.010-inch-thick stecl, "Tomato Can"

- Outermost can: 4.25 -inch-diameter by 7 -inch-tall by 0.010 -inch-thick (ends) by 0.015 -inchthick (sides), steel, "404 x 700 Can."

This configuration was chosen because it is commonly used for plutonium shipments and provides a can size that is easy to handle and store. Helium evolution of the Np-237 and the U-232 impurity was evaluated and found to be insignificant. Therefore, the food pack cans described above should be suitable for long-term storage.

\section{DOSE STUDY}

Dose studies proved to be the most difficult of the tasks because of the lack of a well defined source term. Neptunium oxide has not been produced since the mid-1980s and the HB conversion line at the Savannah River Site has never been run. Past experience has shown that the impurity levels can very over a broad range depending on the feed material and the separation requirements. Below are some preliminary analyses based on the best available information.

Analyses were made for three isotopic contents: the worst case isotopic composition expected from the new HB line at Savannah River and two measured samples, one supplied the "measured minimum source" and the other supplied the "measured maximum source." Table 1 presents a comparison of the calculated dose rates from these sources for material aged 30 days. The computation was made for triply encapsulated powder as described above for internal packaging (the can was assumed to be completely filled). All calculations were made using a neptunium oxide powder density of $2.2 \mathrm{~g} / \mathrm{cm}^{3}$. The higher concentrations of the U-232 and Th-228 isotopes in the worst case and measured maximum case (part of the Pu-236 decay chain that eventually leads to Tl-208, having about a $3-\mathrm{MeV}$ gamma) produced exceedingly high dose rates.

Only the dose rates calculated for the minimum source measurement approich a reasonable level for handling. Including the isotopes from the U-232 decay chain causes dose rates well beyond an ability to handle without significant shielding for transportation. However, to meet acceptable dose limits for handling within a facility as defined by DOE Order 5480.11 , the quantity of material within the storage can may need to be limited, the storage can may require additional shiclding, or remote handling may be required to limit the total worker dose.

Table 1 Average Calculated Gamma Dose Rates from Neptunium Oxide with 0.5 wt $\%$ U-232 (Average Dose Rates [R/hr] Outside an Inner Can 3.5-in-OD by 3.5-in-high)

\begin{tabular}{|c|c|c|c|}
\hline $\begin{array}{c}\text { Distance } \\
\text { from Side }\end{array}$ & $\begin{array}{c}\text { Measured } \\
\text { Minimum Source }\end{array}$ & $\begin{array}{c}\text { Measured } \\
\text { Maximum Source }\end{array}$ & $\begin{array}{c}\text { Estimated Worst } \\
\text { Case Impuritics }\end{array}$ \\
\hline Surface & 14.68 & 915,000 & $1,562,800$ \\
$1 \mathrm{~cm}$ & 10.19 & 636,000 & $1,083,600$ \\
$10 \mathrm{~cm}$ & 1.82 & 112,400 & 192,200 \\
$50 \mathrm{~cm}$ & 0.14 & 8,662 & 14,700 \\
$1 \mathrm{~m}$ & 0.04 & 2,388 & 4,047 \\
\hline
\end{tabular}

Table 2 shows the resulting dose rate of neptunium oxide for four inner can sizes after a 30 day decay time. For all cases, the inner can was assumed to be completely filled with powder. Calculations were made using the isotopic content for the measured minimum source term material. The fourth column represents the same configuration used above in Table 1. In this case, the calculated average dose rate is $14.7 \mathrm{R} / \mathrm{hr}$ at the can surface and $0.04 \mathrm{R} / \mathrm{hr}$ at $1 \mathrm{~m}$ for material in equilibrium. For this configuration 
with freshly separated material and no subsequent decay, the average dose rate is $3.4 \mathrm{R} / \mathrm{hr}$ at the surface and $0.01 \mathrm{R} / \mathrm{hr}$ at $1 \mathrm{~m}$. The neutron contribution to the dose rate is less than $0.04 \%$ for the 3.5-in-OD can.

Table 2 Peak and Average Gamma Dose Rates (R/hr) from Nepturium Oxide Decay for Various Can Sizes

\begin{tabular}{|c|c|c|c|c|c|c|c|c|}
\hline \multirow[b]{2}{*}{ Distance } & \multicolumn{2}{|c|}{$\begin{array}{l}4.25 \text {-in-OD } \\
7 \text {-in-high }\end{array}$} & \multicolumn{2}{|c|}{$\begin{array}{l}4.25 \text {-in-OD } \\
1.5 \text {-in-high }\end{array}$} & \multicolumn{2}{|c|}{$\begin{array}{l}\text { 4.0625-in-OD } \\
4.6875 \text {-in-high }\end{array}$} & \multicolumn{2}{|c|}{$\begin{array}{l}\text { 3.5-in-OD } \\
\text { 3.5-in-high }\end{array}$} \\
\hline & Peak & Ave & Peak & Ave & Pcak & Ave & Pcak & Ave \\
\hline Surface & 34.99 & 31.55 & 21.67 & 19.57 & 34.07 & 30.19 & 16.92 & 14.68 \\
\hline $1 \mathrm{~cm}$ & 24.30 & 21.21 & 11.08 & 10.21 & 22.31 & 19.13 & 11.58 & 10.19 \\
\hline $10 \mathrm{~cm}$ & 5.21 & 4.69 & 1.14 & 1.14 & 3.65 & 3.44 & 1.89 & 1.82 \\
\hline $50 \mathrm{~cm}$ & 0.42 & 0.41 & 0.08 & 0.08 & 0.27 & 0.26 & 0.14 & 0.14 \\
\hline $1 \mathrm{~m}$ & 0.12 & 0.11 & 0.02 & 0.02 & 0.07 & 0.71 & 0.04 & 0.04 \\
\hline
\end{tabular}

None of these calculations include the presence of the external packaging and are therefore conservative. However, even with the best case decay chain, the dose rate on contact remains fairly high for these quantities of material if the material is allowed to age. In fact, for the best case, the dose rate will continue to rise after 30 days due to the gradual decay of $\mathrm{Pu}-236, \mathrm{Bi}-212$, and Tl-208.

The DOT allowable dose limits are $0.2 \mathrm{R} / \mathrm{hr}$ at the package surface and $0.01 \mathrm{R} / \mathrm{hr}$ at $1 \mathrm{~m}$. Shielding needs and final packaging selection cannot be accomplished until the actual source term and exposure levels are established. Because the low-energy gamma rays are fairly easily shiclded, the two surrounding food pack cans, the inner vessel, and 30)- and 35-gallon drums will provide additional shielding. In all shipping packages discussed above, the inner vessel is 0.25 inches thick. Alone, this quantity of steel will reduce the dose by an order of magnitude. The resulting shipping package should easily meet DOT requirements, especially if the material is shipped as fresh as possible with a minimum U-232 content.

\section{CONSIDERATIONS AND RECOMMENDATIONS}

The preferable packaging is the SR-Chalfant 30 Single or 35 Double for immediate use. If the time frame is several years into the future, the SafKeg should be seriously considered, however, the extra cost of the packaging must be considered. The choice of shipping package will ultimately depend upon the expected dose rate of the shipped material. The choice of food pack cans and quantity of material per can will be dependent upon the handling requirements of both the shipper and receiver, taking into consideration the new DOE allowable dose limits. Until a reliable source term is defined, a packaging, choice cannot be positively determined.

Receipt inspection using NDA techniques appears achievable. It needs to be tailored to the anticipated source term to develop the most cost effective and accurate system. The FMEF proves to be a viable storage location requiring a minimum amount of upgrading to receive and store the fucl. However, until a source term can be agreed upon, the anticipated dose rates and handling requirements cannot be determined. Because the dose rate is highly dependent upon the isotopic content, a product specification should be developed in conjunction with the Savannah River Site. This would ensure that appropriate impurity levels and isotopic content can be achieved such that shipped material can be handled both at the time of shipment as well as in the future.

Storage of the material at Hanford allows for an autumated system, minimizing operator exposure. With only minor changes to the facility, a reliable, safe, and secure area is available for long-term storage of neptunium. 
Retaining the neptunium inventory will not be frec, but it should not be inordinately expensive, especially if the facility costs at the FMEF can be shared with other projects. If the neptunium is allowed to enter the waste stream, the ultimate costs are only deferred until waste processing and disposal is addressed. It effectively eliminates the option of domestically producing $\mathrm{Pu}-238$ for space and terrestrial applications from the United States.

\section{Acknowledgments}

This study was sponsored by the DOE, Office of Special Applications as a subtask under contract number DE-AC06-87RL10930.

The authors also wish to thank J. W. Hales and G. E. Culley for their advice and guidance.

\section{References}

DOE, 1993, Control and Accountability of Nuclear Materials, Order 5633.3A, Chapter 2, item 5, U.S. Department of Energy, Washington, D.C.

DOE-RL, 1988, Environment, Safety, and Health Program fo Department of Energy Operations for Richland Operations, Order 5480.1A, Chapter 3 , p. iii, U.S. Department of Energy, Richland Operations Office, Richland, WA.

DOE, 1991, Radiation Protection fo Occupational Workers, Order 5480.11, U.S. Department of Energy, Richland Operations Office, Richland, WA.

R. L. Brodzinski and P. J. Turner, "Nuclear Waste Drum Assayer," Proceedings of the Waste Management '90, Tucson, AZ, March 1990, PNL-SA-17315.

Kecpin, "New Mcthods and Techniques in Nuclear Safeguards Research and Development," Proceedings of the international Conference on Constructive Uses of Atomic Energy, sponsored by the American Nuclear Society and the Atomic Industrial Forum, Washington, D. C. November 10-15, 1968. Published by the American Nuclear Socicty, 1969.

H. E. Martz, G. P. Roberson, C. Robert-Coutant, D. J. Schwcberk, D. C. Camp, "Quantitative Waste Assay Using Gamma-Ray Spcctrometry and Computed Torrography," Proceedings of the 14th Annual European Safeguards Research and Development Association, Salamanca, Spain, May 1992.

D. H. Menlove and G. W. Eccleston, "High-Sensitivity Measurements for Low-Level TRU Waste Using Advanced Passive Neutron Techniques," Proceddings of the Transuranic Waste Characterization Conference, Idaho State University, ID, August 1992.

N. J. Nicholas, K. L. Coop, R. J. Estep, Capability and Limitation Study of the DDT Passive-Active Neutron Waste Assay Instrument, Los Alamos National Laboratory, Los Alamos, NM, 1992, LA-12237-MS DE92 011758. 


\section{DISTRIBUTION}

Number of Copies

\section{OFFSITE}

1

U.S. Department of Energy,

Headquarters

19901 Germantown Road

Germantown, Maryland 20874

A. S. Mehner NE-50

ONSITE

2

U.S. Department of Enerqy, Richland Operations office

0. A. Farabee

N1-39

R. G. Hastings

N1-39.

11

Westinghouse Hanford Company

C. J. Alderman

NI-21

G. E. Culley

J. R. Frederickson

NI-21

J. W. Hales

R. A. Schwarz

$\mathrm{N} 1-42$

L5- 02

R. J. Smith

HO-35

D. W. Wootan

M. J. Wiemers

G2-02

$\mathrm{HO}-40$

Document Processing and Distribution (2)

Information Release

Administration

N1-21

L8-05

L8-07 

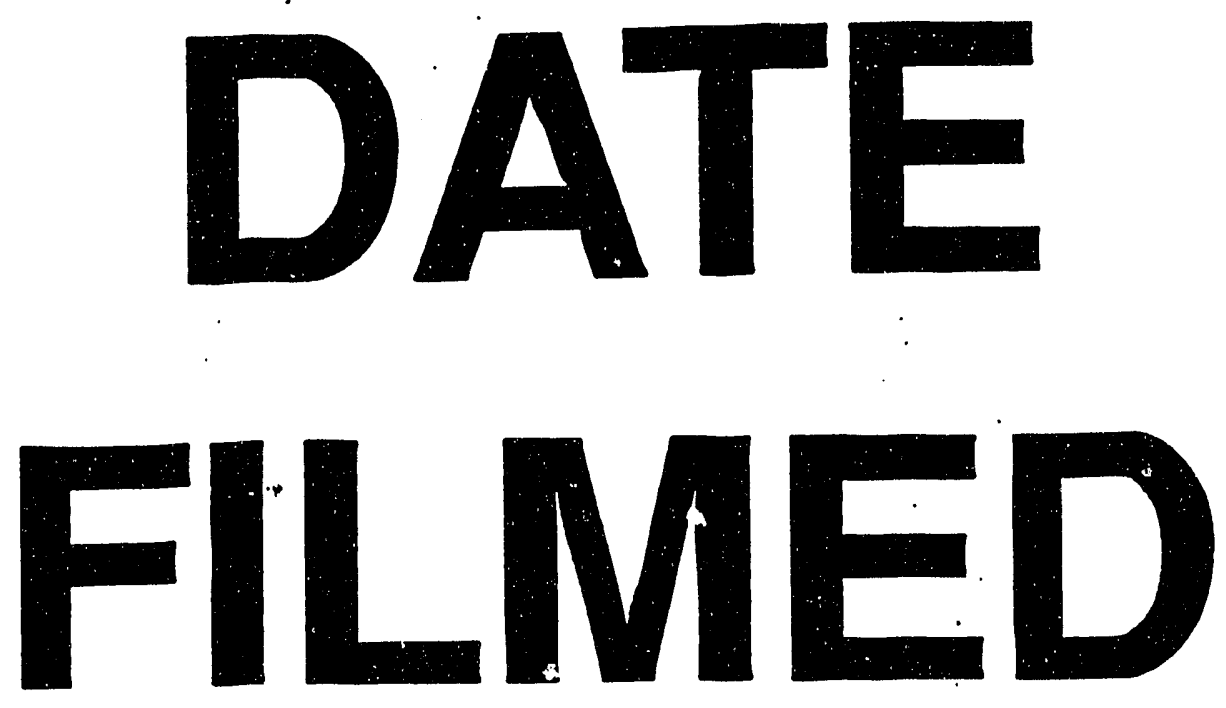

$12 / 14 / 93$
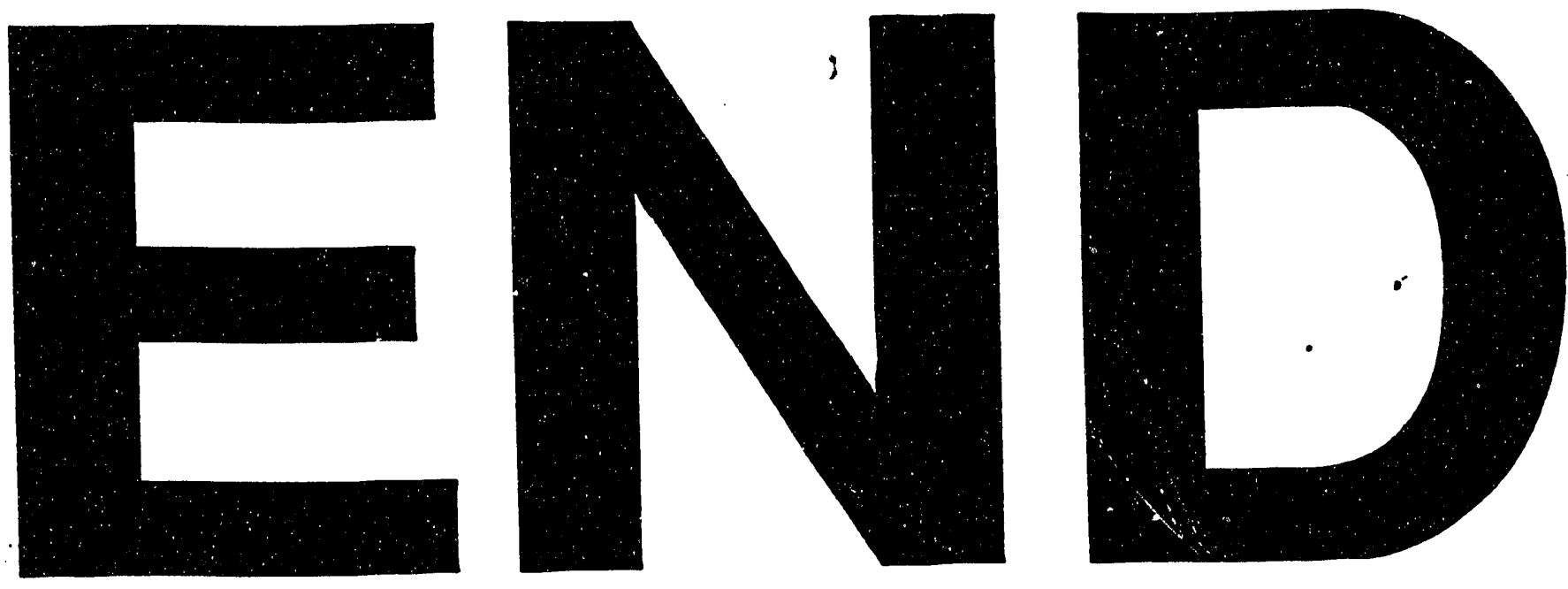
